\title{
The Atmospheric Pressure Observations 1856-1858 by Father Louis Furet, at Naha, Japan
}

\author{
Gaston R. DEMARÉE* , Pascal MAILIER* , Patrick BEILLEVAIRE** , \\ Takehiko MIKAMI $^{* * *}$, Masumi ZAIKI ${ }^{* * * *}$, Togo TSUKAHARA ${ }^{* * * * *}$, \\ Yoshio TAGAMI ${ }^{* * * * * *}$ and Junpei HIRANO ${ }^{* * *}$
}

[Received 24 July, 2017; Accepted 12 February, 2018]

\begin{abstract}
Father Louis Théodore Furet (1816-1900) was a missionary of the Société des Missions étrangères de Paris (Paris Foreign Missions Society) who was posted in the Far East from 1853 to 1869. The discovery of his manuscript of meteorological observations undertaken at Naha, Okinawa, Ryukyu Islands, Japan, opens up new perspectives on the historical climatology of $19^{\text {th }}$ century Japan. Furet arrived at Naha (spelled Nafa in the $19^{\text {th }}$ century literature), the main port of Okinawa, on 26 February 1855. From December 1856 to September 1858, he carried out meteorological observations five times a day: at 6 and $10 \mathrm{am}, 1,4$ and $10 \mathrm{pm}$. The hydrological engineer Alexandre Delamarche $\left(1815^{-1884)}\right.$ calibrated the meteorological instruments entrusted to Father Furet by the French Dépôt de la Marine. The observations were carried out following the meteorological procedures in use in France in the 1850s. The atmospheric pressure data are given by the barometer readings, the barometer-temperature readings and the computed temperature-corrected atmospheric pressure. The pressure data are controlled and corrected, where necessary, using the Delcros and Haeghens formula which was in use in the $1850 \mathrm{~s}$. The historical atmospheric pressure observations are compared to the present-day long-term averages at Naha. During his observation period a typhoon was witnessed by Father Louis Furet on 18 May 1857. Other low atmospheric pressure observations probably correspond to extra-tropical storms. In such an event, the Dutch ship van Bosse was wrecked near the island Tarama but the captain, his wife and the whole crew survived. They were helped by the inhabitants of the island and were later transferred to Naha, Okinawa, where they met the three French missionaries and finally got a passage from the Dutch trading post at Decima to Batavia (present-day Jakarta).
\end{abstract}

Key words : 1850s, atmospheric pressure, Japan, Louis Furet, meteorological observations, Ryukyu Islands

\footnotetext{
* Royal Meteorological Institute of Belgium, B-1180 Brussels, Belgium

** French National Center for Scientific Research, Japan Research Center, EHESS, Paris, France

*** Faculty of Liberal Arts, Teikyo University, Hachioji, 192-0395, Japan

**** Faculty of Economics, Seikei University, Musashino, 180-8633, Japan

***** Graduate School of Intercultural Studies, Kobe University, Kobe, 657-8501, Japan

****** Faculty of Human Development, University of Toyama, Toyama, 930-8555, Japan
} 


\section{Introduction}

In Japan, non-instrumental meteorological information extracted from the numerous weather diaries is a rich source of historical climate evidence (Mikami, 1999; Hirano and Mikami, 2008; Mikami et al., 2015). However, instrumental meteorological observations in Japan in the $18^{\text {th }}$ and first half of the $19^{\text {th }}$ century remain rare. Reliance has to be placed primarily on the observations carried out by the Dutch East India Company and its successor, the Dutch trading post at Dejima, Nagasaki. (Demarée and Mikami, 2000; Demarée et al., 2013a, b; Können et al., 2003; Zaiki, 2004).

Father Louis Furet, accompanied by two fellow missionaries from the Missions étrangères de Paris, arrived on Okinawa Island, commonly named Grande île Loutchou in Furet's papers, on 26 February 1855. They disembarked at Naha, the main port of the semi-independent kingdom of Ryukyu, a tribute state of China since the $14^{\text {th }}$ century which also came under the domination of Japan in 1609. It is clear from $19^{\text {th }}$ century scientific literature that it was known then that Furet carried out meteorological observations at Naha. However, this knowledge was limited to information regarding monthly means of the period December 1856-September 1858 (Furet, 1859a, b, 1860).

The discovery of the manuscript A00045d Furet $1853-1860^{1)}$ in the Archives of MétéoFrance has opened up possibilities for shedding light on the meteorological conditions of mid$19^{\text {th }}$ century Japan. The manuscript consists of four different parts: (a) Furet's meteorological observations during his ship journey from 20 May 1853 until his arrival at Hong-Kong on 7 October 1853; (b) his letters to Charles SainteClaire Deville; (c) the daily meteorological observations from 18 December 1856 to 30 September 1858; and (d) the summaries for the years 1857, 1858, 1859, and 1860. The seismological information contained in the ms. A00045Furet 1853-1860 and partly published in Furet (1859a) was published extensively in Demarée et al. (2016). Descriptive accounts in the manuscripts referred to in this paper have been translated by G. Demarée and by P. Beillevaire, co-authors of this paper.

\section{Milestones in the life of Father Furet}

Louis Théodore Furet was born on 25 March 1816 at Commer, a small village in the French department of Mayenne, near the town of the same name. After graduating from the college of Mayenne, he entered the seminary of Le Mans in 1837 and was ordained a priest there in 1839. From 1845 to 1847 , he was in Paris at the College Stanislas attending classes in physics, chemistry and natural sciences while also studying mathematics at the Sorbonne. In 1852, he entered the seminary of the Missions étrangères de Paris. On 19 April 1853, he left the seminary for Hong Kong to be posted as a missionary in Sichuan, China, as had been agreed. However, circumstances decided otherwise. Following the signing of the Kanagawa Treaty on 31 March 1854 between Japan and the United States, it was hoped that Japan would continue to open itself to western trade and residents. Consequently the responsible in charge of the Procure of the Missions étrangères de Paris in China chose to send Father Furet to the Ryukyu Islands with the aim of preparing for missionary work in Japan.

An aborted opportunity to participate in the first British-French naval operation in the framework of the Crimean War (1853-1856) forced Furet to leave Okinawa as early as May 1855 and to withdraw to Hongkong. The following year, however, he was invited to join the second operation designed to visit Ezo and explore the Russian defenses in the Strait of Tartary. After the expedition had been completed, Furet returned to China from where he was carried back to Naha on 26 October 1856. He was then able to resume his meteorological observations. Father Furet withdrew from Okinawa in October 1862. He stayed successively in Nagasaki from January 1863 to October 1864 and from June 1866 to June 1867, after a year spent in France, and in Yokosuka and Yokohama until October 1869. He then returned to 
France where he became a parish priest (Beillevaire, 1999, 2013, 2018).

\section{Father Furet's meteorological observations}

Around the middle of the $19^{\text {th }}$ century, several efforts contributed to the development of meteorology as a science. In France, three scientists: J. Haeghens, Charles Martins and Louis Adolphe Bérigny, published the Annuaire Météorologique de France in 1848. In 1852, the meteorologists Émilien Renou and Charles Sainte-Claire Deville founded the Société Météorologique de France, and the Annuaire became the Annuaire de la Société Météorologique de France.

In Belgium, the First International Maritime Conference for Devising an Uniform System of Meteorological Observations at Sea was held in Brussels in August and September 1853 under the Presidency of Adolphe Quetelet, Director of the Royal Observatory of Brussels. Alexandre Delamarche, ingénieur hydrographe of the French Marine, represented France at the Brussels Conference. Delamarche also calibrated the meteorological instruments entrusted to Father Furet by the French Dépôt de la Marine.

The meteorological observations carried out at sea by Furet during his travel from Brest to Hong Kong are recorded on pre-printed sheets very much in line with the format suggested by the Brussels maritime conference. It is not known which instructions for carrying out meteorological observations Father Furet followed in Naha as no information about the document is given. However, a bibliographical search pointed to the Instruction sur les Observations météorologiques à faire dans les Hôpitaux coloniaux which was published as an extract of the Revue coloniale of February 1852 (Anonymous, $1852,1874)$. Indeed, the meteorological observations carried out by Father Furet are fully compliant with these instructions. In particular, the temperature corrections of the barometer readings were done by the formula and subsequent tables proposed by Delcros and Haeghens (1853).
From 2 April until 4 May 1855, Father Furet carried out meteorological observations four times a day at $6 \mathrm{am}, 10 \mathrm{am}, 2 \mathrm{pm}$ and $6 \mathrm{pm}$ at a small monastery named Seigenji, in the district of Amiku, in the village of Tomari, bordering the sea just north of Naha. The observations were interrupted by Furet's departure to Nagasaki followed by his stay in Hong Kong (see section II). His meteorological observations were taken up again after his return to Okinawa in 1856. The French missionaries had left the monastery at Amiku and now lived in a house that had been built for them on the hill of Matsuo at Kumemura, an old village that had become part of Naha and which was inhabited by the descendants of Chinese immigrants (Beillevaire, 1999 $)^{2)}$.

From December 1856 to September 1858, Father Furet carried out meteorological observations five times a day, at $6 \mathrm{am}, 10 \mathrm{am}, 1 \mathrm{pm}$, $4 \mathrm{pm}$ and $10 \mathrm{pm}$. These observations were recorded on monthly sheets, one for each observation hour. These sheets contain the decadal and monthly means of the temperature-corrected atmospheric pressure and of the (dry bulb) air temperature. Daily means are calculated on separate sheets named résumé du mois. These daily means consist of daily mean atmospheric pressure, the daily oscillation in the temperature-corrected atmospheric pressure values, the 6 am and $1 \mathrm{pm}$ air temperature readings and their averages, the averages of the 6 and 10 am and 4 and $10 \mathrm{pm}$ air temperature readings, water vapour pressure, relative humidity, the description of rainfall from 6 am to $6 \mathrm{pm}$ and from $6 \mathrm{pm}$ to $6 \mathrm{am}$, and occasionally the rainfall in 24 hours, and ending with general weather observations. It is not known how the daily mean atmospheric pressure was calculated (Demarée et al., 2015).

Father Furet continued to carry out meteorological observations after September 1858. However, the daily records are not included in the manuscript at the Archives of Météo-France. Annual sheets for 1857, 1858, 1859, and 1860 provide monthly means for air temperature, water vapour pressure, relative humidity, and 
atmospheric pressure (only until September 1858) as well as seismological information (see Demarée et al., 2016). It is not known exactly how Furet calculated the daily means; monthly means are the average of the three decadal means. Extending the atmospheric pressure data into the time span 1859 and 1860 is not possible as the barometer broke down ${ }^{3)}$ and, therefore, no atmospheric pressure data are available in Furet's observations after 23 September 1858.

\section{Father Furet's atmospheric pressure observations}

The Furet A00045d manuscript contains the 5 -times daily atmospheric pressure observations (Table 1). These are reported as follows: the barometric readings, the barometer-temperature readings and the atmospheric pressure adjusted with the computed barometer- temperature correction. It is thought that the barometer was located inside the house due to the fragile nature of the instrument. This is also suggested by the differences between the temperature readings of the barometer and the (dry bulb) air temperature readings which are variable and follow a winter-summer pattern.

Bibliographical research followed by computational verification allowed for the identification of the temperature correction for barometric readings as the formulae presented by Delcros and Haeghens (1853).

$$
\begin{aligned}
h_{t} & =h-h(0.0001614 t) \\
& =h-h\left(\frac{t}{6196}\right)=h\left(1-\frac{t}{6196}\right)
\end{aligned}
$$

where $h$ is the barometric reading, $t$ the temperature of the barometer expressed in ${ }^{\circ} \mathrm{C}$ and $h_{t}$ the temperature-corrected atmospheric pres-

Table 1 Monthly number of atmospheric pressure observations for the five observation hours.

\begin{tabular}{cccccccc}
\hline year & month & no. days & $6: 00$ AM & $10: 00$ AM & $1: 00$ PM & $4: 00$ PM & 10:00 PM \\
\hline 1856 & Dec & 31 & 14 & 14 & 13 & 12 & 14 \\
1857 & Jan & 31 & 29 & 26 & 24 & 26 & 29 \\
& Feb & 28 & 28 & 27 & 22 & 21 & 28 \\
& Mar & 31 & 31 & 30 & 24 & 20 & 30 \\
& April & 30 & 29 & 27 & 26 & 24 & 30 \\
& May & 31 & 31 & 29 & 17 & 26 & 31 \\
& Jun & 30 & 30 & 29 & 15 & 23 & 30 \\
& Jul & 31 & 31 & 27 & 22 & 25 & 31 \\
& Aug & 31 & 31 & 21 & 19 & 16 & 30 \\
& Sep & 30 & 30 & 14 & 16 & 18 & 26 \\
& Oct & 31 & 30 & 18 & 14 & 16 & 28 \\
& Nov & 30 & 29 & 25 & 14 & 23 & 29 \\
& Dec & 31 & 30 & 25 & 17 & 19 & 30 \\
& Jan & 31 & 29 & 29 & 14 & 20 & 31 \\
& Feb & 28 & 27 & 27 & 16 & 14 & 28 \\
& Mar & 31 & 31 & 21 & 24 & 15 & 31 \\
& April & 30 & 25 & 21 & 17 & 14 & 29 \\
May & 31 & 31 & 26 & 22 & 19 & 31 \\
& Jun & 30 & 27 & 28 & 23 & 18 & 29 \\
& Jul & 31 & 27 & 28 & 21 & 19 & 31 \\
& Aug & 31 & 26 & 28 & 20 & 19 & 30 \\
& Sep & 30 & 20 & 22 & 18 & 10 & 23 \\
\hline
\end{tabular}




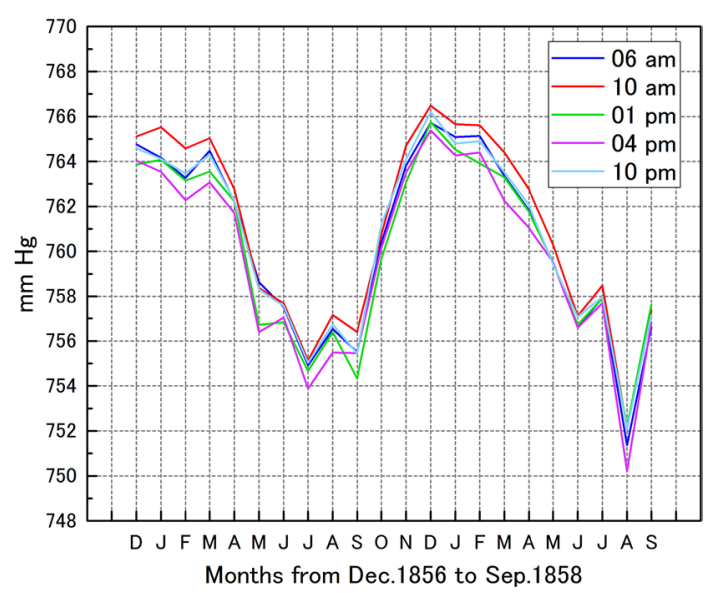

Fig. 1 The monthly atmospheric pressure at the 5 observational times: $6 \mathrm{am}, 10 \mathrm{am}, 1 \mathrm{pm}, 4 \mathrm{pm}$ and $10 \mathrm{pm}$.

sure. Furet would have used tables such as the ones attached to the publication by Delcros and Haeghens (1853). All barometric data have been digitized and controlled for errors using the above formula.

Although Father Furet was present at Naha during the entire observational period, observations were not always carried out, particularly during the daytime hours. Figure 1 and Figure 2 show monthly atmospheric pressures from December 1856 to September 1858.

The difference in September 1857 results mainly from the two different ways of computing the averages. The period with minimummean atmospheric pressure from May to October corresponds to the typhoon season when the intertropical convergence zone (ITCZ) migrates far enough north from the equator.

Figure 3 represents the comparison between the Furet monthly averaged temperature-corrected atmospheric pressure data for the year 1857 (blue color), the year 1858 (red color) and the Naha Air Base present-day data averaged over the years 2009 through 2016. The data show a good comparison regarding the maxima and the minima levels. In July and August of the year 1858, the data deviate slightly. This could be due to different weather patterns.

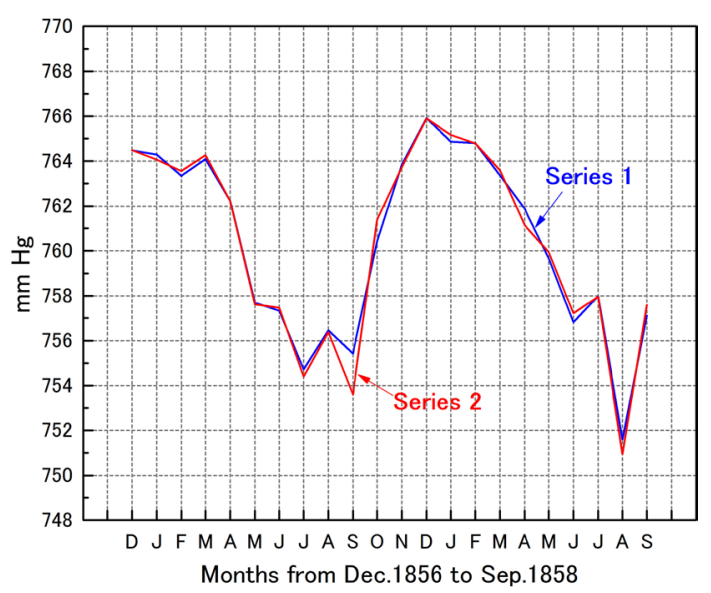

Fig. 2 Monthly mean temperature corrected atmospheric pressure data. Series 1 corresponds to the daily mean atmospheric pressure data. Series 2 is taken from Furet's monthly means computed as the average of his decadal means (Furet, 1859a).

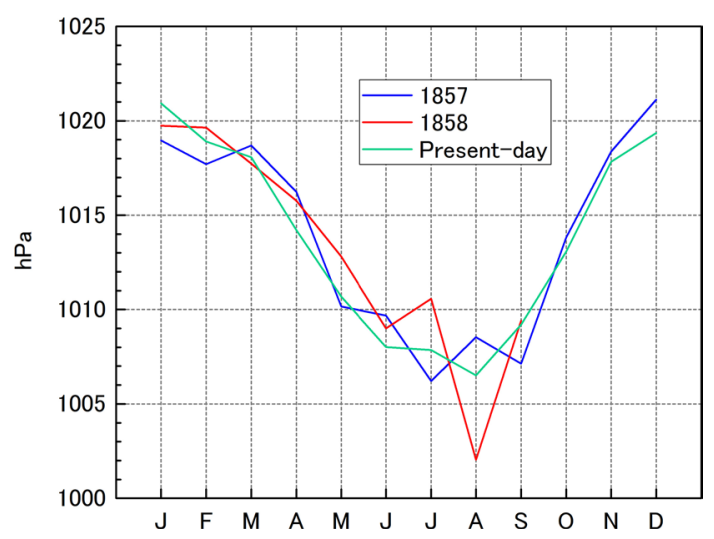

Fig. 3 Furet temperature corrected atmospheric pressure data for the years 1857, 1858 and the Naha Naval Base data averaged over the years 2009 through 2016.

\section{The Typhoon of 18 May 1857}

The passage of a typhoon was witnessed on 18 May 1857, and described as follows: Typhoon of 18 May. Typhoons are very rare at this time of year on Grande Lou-Tchou. This one has not been violent, according to the inhabitants.

Figure 4 represents the detailed tempera- 


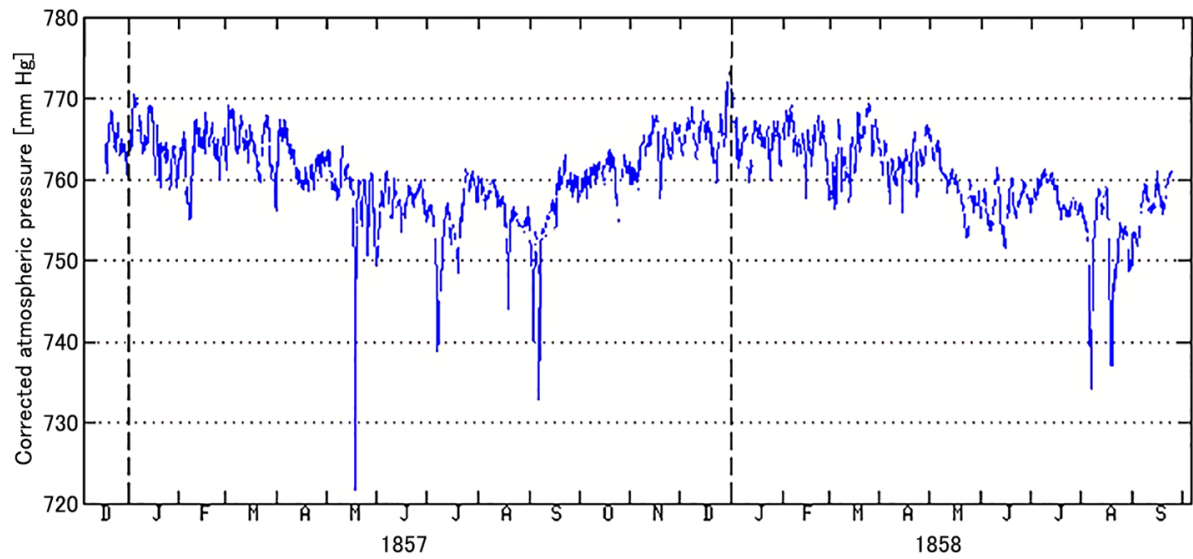

Fig. 4 The Furet temperature corrected atmospheric pressure data, as observed by Furet in mm $\mathrm{Hg}$, from 18 December 1856 to 24 September 1858 representing the 5 times a day observations.

ture-corrected atmospheric pressure data given by Father Furet (see sheet Mai 1857, résumé du mois). The corresponding rainfall is described as follows: on 16 May: rainfall between 12 and around 2 in the day, moderate rain during one and a half hours; on 17 May: light rain, moderate rain, heavy rain and torrential rain the whole day; 18 May: moderate rain, heavy rain during part of the day (typhoon); 19 May: light rain from 6 am to 7.30 am for one and a half hours.

By plotting the detailed temperature-corrected atmospheric pressure data (in $\mathrm{mm} \mathrm{Hg}$ ) on 18 May 1857, the day of the typhoon is distinguishable as shown in Fig. 4 and Table 2.

\section{The Shipwreck of the van Bosse near Tarama Island}

Extra-tropical storms with low atmospheric pressure patterns were observed in a number of cases as may be seen from Table 2. In one such storm, the van Bosse, a three-mast barque, built in 1854 in Germany and used by Bonke and Co. Trading at Rotterdam, was shipwrecked on its way from Shanghai to Singapore at Tarama island in Okinawa Prefecture. On board were Captain W.E. Hageman, his wife, and a crew of 25. The van Bosse left Shanghai on 5 July 1857 , and on the 15 July, in view of the island Kokinsan, heavy storm weather was
Table 2 The low temperature corrected atmospheric pressure data in the tome series. No altitude and gravimetrical correctios are applied to the atmospheric pressure data.

\begin{tabular}{rcrrrr}
\hline \multicolumn{3}{c}{ Date } & & & \\
year & month & day & & & \\
\cline { 1 - 2 } 1857 & May & 18 & 16 & 721.6 & 962.1 \\
& Jul & 7 & 16 & 738.9 & 985.1 \\
& Sep & 3 & 6 & 740.2 & 986.9 \\
& & 6 & 22 & 732.7 & 976.9 \\
\multirow{2}{*}{1858} & Aug & 6 & 22 & 734.2 & 978.9 \\
& & 7 & 6 & 738.0 & 983.9 \\
& & 19 & 13 & 737.0 & 982.6 \\
\hline
\end{tabular}

experienced which increased in intensity the next morning. The ship prepared for a typhoonlike storm with heavy showers of rain. During the night of 17 to 18 July 1857, at 3 o'clock in the morning, the ship ran aground and took on water. Everyone was saved on two sloops and by daylight they landed on an unknown island surrounded by hundreds of natives. They were treated kindly and taken to the interior of the island where they remained for eight days. They were then transferred to the island of Typinsan (Miyako Island) where they stayed for a whole month. Upon being transferred to Grande Lou-Tchou, they found three French 
missionaries (among them Louis Furet) who shared with the shipwreck survivors some of the few clothes they had. They were surprised by the arrival of the ship Jan Daniel captained by H. Hagers, on 9 November 1857. She had been sent to Naha at the request of Donker Curtius, Opperhoofd of the Dutch trading post at Decima, and who had been informed by the Ryukyu authorities that the shipwrecked crew was in Naha. They finally arrived in Batavia, Dutch East India on 2 December 1857 (see the Dutch newspapers: Java-Bode; De Oostpost $)^{4)}$. Information regarding the shipwreck of the van Bosse and the rescue of the crew reached The Netherlands early in February 1858.

Although the distance between Tarama island and Okinawa is a mere $350 \mathrm{~km}$, the Furet meteorological manuscript provides indications of the stormy weather conditions. The wind strength is noted 4 (= heavy wind strength) and a temperature-corrected atmospheric pressure dip of $748.4 \mathrm{~mm} \mathrm{Hg}(=997.78 \mathrm{hPa})$ was observed on 20 July. In the autumn of 2016 a Japanese-Dutch research project conducted exploratory maritime archeological research on the van Bosse shipwreck at Tarama ${ }^{5)}$.

\section{Conclusions}

The observations carried out by Father Furet constitute a valuable set of meteorological data at the end of the Seclusion period of Japan, a time-frame in which meteorological observations remain still very rare in and around Japan. The dataset might also be useful in determining weather conditions of the mid $1850 \mathrm{~s}$ and particularly in the assessment of tropical storms in this area of the Far-East.

Temperature-corrected atmospheric pressure data in Naha, Okinawa, Japan, have been studied for the period December 1856-November 1858 using a set of observations carried out five times daily by Father Louis Furet. One typhoon was witnessed on 18 May 1857. The passage of extra-tropical storms can also be noticed in other instances.

\section{Acknowledegements}

The authors express their sincere gratitude to MM. Pierre Paillot and Xavier Popibeau, METEOFRANCE/DIRCOM/DOC, for their valued help in locating the Furet manuscript at the Archives of MétéoFrance, its description and its consultation.

\section{Notes}

1) Furet, le Père. Manuscrit: Napa (Ile Loutchou) $\mathrm{Obs}^{\mathrm{s}} \mathrm{du}$ Père Furet 1853, 1857-1860. Archives Météo-France A00045d Furet 1853-1860.

2) Maritime Conference held at Brussels for Devising an Uniform System of Meteorological Observations at Sea. August and September 1853. Conférence maritime tenue à Bruxelles pour l'adoption d'un système uniforme d'observations météorologiques à la mer. Août et septembre 1853. Bruxelles, Hayez, 125p., Annexes.

3) Cosmos, Revue encyclopédique hebdomadaire des Progrès des Sciences et de leurs Applications aux Arts et à l'Industrie. Fondée par M. B.-R. de Monfort, Rédigée par M. l'abbé Moigno. Tome quatorzième (1859), p. 206-207.

4) De Oostpost, Donderdag 10 December 1857, printed at Soerabaya. Java-bode, Zaterdag 5 December 1857, printed at Batavia.

5) https://maritiemprogramma.wordpress.com/2016/ 08/23/japanese-dutch-research-on-shipwreck-vanbosse-about-to-begin/ [Cited 2017/7/24].

\section{References}

Anonymous (1852): Instruction sur les Observations météorologiques à faire dans les Hôpitaux coloniaux. Extrait de la Revue coloniale (Février 1852), 46p.

Anonymous (1874): Instruction sur les Observations météorologiques à faire dans les Hôpitaux coloniaux. Revue maritime et coloniale, tome 40, Ministère de la Marine et des Colonies, Paris, 51-78.

Beillevaire, P. (1999): Un missionnaire aux îles Ryukyu et au Japon à la veille de la Restauration de Meiji: Louis Furet (1816-1900). Paris, Archives des Missions étrangères, Études et documents (7), Églises d'Asie, Série Histoire, 248p.

Beillevaire, P. (2013) : Présences françaises à Okinawa -De Forcade (1844-1846) à Haguenauer (1930). Ebisu, Études japonaise, 49, printemps-été 2013, 133-164.

Beillevaire, P. (2018) : Father Louis Furet, Missionary of the Paris Foreign Missions Society: His life and scientific observations on Okinawa (1855-1862). Journal of Geography (Chigaku Zasshi), 127, 483501.

Delcros, J. and Haeghens, J. (1853): Tables pour la réduction à zéro de la colonne mercurielle du baromètre, Mesurée sur les échelles de laiton étalonnées à zéro; Calculées de 5 à 5 millimètres de degré 
en degré centigrade, de 260 à 855 millimètres, Par M.J. Delcros, suivies d'autres tables pour les hauteurs barométriques comprises entre 605 et 800 millimètres, Calculées de dixième en dixième de degré, depuis $0^{\circ}$ jusqu'à 34, par M.J. Haeghens. Annuaire météorologique de la France. $4 \mathrm{e}$ année, 41-72.

Demarée, G.R. and Mikami, T. (2000): Some XVII-th and XVIII-th century Dutch climatological observations at Deshima, Nagasaki, (Japan), seen as a complement to Japanese climatological historical documents. in Proceedings of the International Conference on Climate Change and Variability-Past, Present and Future, Tokyo Metropolitan University, 13-17 September 1999 edited by Mikami, T., 107113.

Demarée, G.R., Mikami, T., Tsukahara, T. and Zaiki, M. (2013a): In the Wake of De Liefde-The Instrumental Meteorological Observations of the Vereenigde Oost-Indische Compagnie (VOC). Bull. Séanc. Acad. R. Sci. Outre-Mer-Meded. Zitt. K. Acad. Overzeese Wet., 59 (2-4), 387-407.

Demarée, G.R., Mikami, T., Tsukahara, T. and Zaiki, M. (2013b): The meteorological Observations of the Vereenigde Oost-Indische Compagnie (VOC) What can be learned from them?. Historical Geography, $\mathbf{5 5}(5)$, 99-106.

Demarée, G.R., Beillevaire, P., Tsukuhara, T., Mikami, T., Zaiki, M. and Tagami, Y. (2015): The story of the meteorological observations of Jean Barthe, Physician on the French Frigate La Sibylle, and of Father Furet, Apostolic Missionary in Okinawa. Bull. Séanc. Acad. R. Sci. Outre-Mer-Meded. Zitt. K. Acad. Overzeese Wet., 61 (2-3), 469-487.

Demarée, G.R., Beillevaire, P., Tsukahara, T., Mikami, T., Tagami, Y. et Zaiki, M. (2016): Les séismes à Okinawa: les observations du Père Louis Furet, missionnaire apostolique. Ciel et Terre, $132(1)$, 210.

Furet, le P. (1859a): Météorologie-Observations météorologiques faites aux îles Lou-Tchou; par le P. Furet, missionnaire apostolique. Comptes rendus hebdomadaires des séances de l'Académie des Sciences, Tome quarante-huitième, janvier-juin 1859, Paris, Mallet-Hachette, 393-396.

Furet, le P. (1859b): Observations météorologiques faites aux îles Lou-Tchou (Séances Académiques. Institut de France-Académie des Sciences, Séance du 28 février 1859). L'Institut, Journal Universel des Sciences et des Sociétés Savantes en France et à l'Étranger, $1^{\mathrm{re}}$ section, $27^{\mathrm{e}}$ Année, $\mathrm{N}^{\circ} 1313,67$.

Furet, le P. (1860): Resultate meteorologischer Beobachtungen auf den Lu-Tschu-Inseln vom Pater Furet, apostolischem Missionar. Repertorium für Meteorologie, redigirt von Dr. Ludwig Friedrich Kämtz. I. Band, Dorpat, 153-154.

Hirano, J. and Mikami, T. (2008): Reconstruction of winter climate variations during the $19^{\text {th }}$ century in Japan. International Journal of Climatology, 28, 1423-1434.

Können, G.P., Zaiki, M., Baede, A.P.M., Mikami, T., Jones, P.D. and Tsukuhara, T. (2003): Pre-1872 extension of the Japanese instrumental meteorological observations series back to 1819. Journal of Climate, 16, 118-131.

Mikami, T. (1999): Quantitative climatic reconstruction in Japan based on historical documents. Bulletin of the National Museum of Japanese History, 81, 41-50.

Mikami, T., Zaiki, M. and Hirano, J. (2015): A history of climatic change in Japan. A reconstruction of meteorological trends from documentary evidence. in Environment and Society in the Japanese Islands from Prehistory to the Present edited by Batten, B.L. and Brown, P.C., 197-212.

Zaiki, M. (2004): Correction and Homogenization of the $19^{\text {th }}$ Century Instrumental Meteorological Records in Japan and its Application for Studying Past Climate Variability. PhD Thesis, Department of Geography, Graduate School of Science, Tokyo Metropolitan University, 80p, 18 Tables, 60 Figures, Appendices.

* Title etc. translated by T.M. 


\title{
那覇（1856-1858 年）におけるフュレ神父の気圧観測
}

\author{
Gaston R. DEMARÉE* ${ }^{*}$ Pascal MAILIER* ${ }^{*}$ Patrick BEILLEVAIRE** \\ 三上岳 彦*** 財城真寿美**** 塚 原 東 吾*****

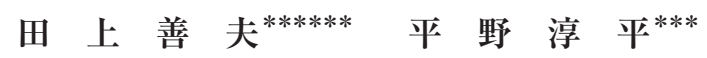

\section{ルイ・テオドール・フュレ神父（1816-1900 年)} は，パリ外国宣教会の宣教師として極東に派遣さ れた。日本の琉球諸島・沖縄の那覇における彼の 気象観測原簿の発見は，19 世紀日本の歴史気候 学に新しい進展を開くものである。フュレは, 1855 年 2 月 26 日に沖縄の主要な港である那覇 （19 世紀の文献では Nafa と綴っていた）に到着 した。1856 年 12 月から 1858 年 9 月まで，彼は 1 日 5 回（午前 6,10 時，午後 $1,4,10$ 時）の 気象観測を行った。水利技師アレクサンドル・デ ラマーシュ（1815-1884 年）は，フランス海軍 兵站部によってフュレ神父に委託された気象測器 の検定を行った。気象観測は，1850 年代のフラ ンスで使われていた気象観測方式に従って実施さ れた。気圧観測データは，気圧計の読みとり值， 気圧計付随温度計の読みとり值，そして温度補正
した気圧の数值で記載されている。気圧データは, 必要に応じて，1850 年代に使われたデルクロス とハイゲンスの公式を用いて検定・補正された。 この歴史的な気圧観測データを現在の那覇におけ る気圧平年值と比較した。観測期間中の 1857 年 5 月に台風が接近通過したことが，ルイ・フュレ 神父によって目撃されている。ほかにも何度か気 圧の低下が観測されているが，おそらく発達した 低気圧の通過によるものであろう。そうしたなか で，オランダ船ファン・ボッセが多良間諸島の近 くで難破したことがあったが，船長と彼の妻や船 員達は島民に救助された。その後, 彼らは沖縄の 那覇に移送されたが，そこで 3 名のフランス人 宣教師と出会い, 最終的に出島のオランダ交易所 からバタビア（現在のジャカルタ）へと航行した。

キーワード：1850 年代, 気圧, 日本, ルイ・フュレ, 気象観測, 琉球諸島

* ベルギー王立気象研究所

** フランス国立科学研究センター・日本研究所

*** 帝京大学文学部

***** 成蹊大学経済学部

****** 神戸大学国際文化学研究科

******* 富山大学人間発達科学部 